\title{
乱流混合過程を含む生態系モデルによる富山湾 クロロフィルaの鉛直分布の変動解明
}

\author{
大橋 充佳 1 松浦 知徳 2 -黒田 雄斗 3 -千葉 元 4 \\ 1富山大学 大学院理工学教育部（†930-8555 富山県富山市五福3190） \\ E-mail:yululu.t@gmail.com \\ 2正会員 富山大学教授 大学院理工学研究部（下930-8555 富山県富山市五福3190） \\ E-mail:matsuura@sci.u-toyama.ac.jp \\ 3富山大学 理学部（干930-8555 富山県富山市五福3190） \\ 4富山高等専門学校教授 商船学科（干933-0293 富山県射水市海老江練合1-2)
}

\begin{abstract}
富山湾沿岸は陸からの栄養塩に富んだ淡水と沖からの塩分の濃い対馬暖流水 (34.5 psu) が合流し, 水産資 源の豊富な良い海洋環境が形成されている。しかし, 近年海洋環境保全の観点から, 湾内の生態系の実態 把握と将来予測が急務な課題となっている. そこで，富山湾沿岸域のクロロフィルaの月ごとの観測デー タを解析するとともに，1次元生態系モデル（NPZモデル）に鉛直拡散項を付加したモデリングを行い, パラメータ（渦拡散係数 $\mathrm{K}_{\mathrm{v}}$, 食植速度 $\mathrm{R}_{\mathrm{m}}$, マクロとミクロ動物プランクトン種）の依存性を定量的に調 ベた。 その結果, 富山湾沿岸域の植物プランクトンの鉛直分布には海洋混合過程が影響していることが示 された。
\end{abstract}

Key Words : Ecosystem modelling, Chlorophyll a,Vertical mixing, Toyama bay

\section{1. はじめに}

富山湾の水塊構造の季節変動特性は, 3 月に水温が極 小となり，鉛直混合が活発になることで水深 $50 \mathrm{~m}$ 付近 まで一様となる. 8 月には水温が最大となり, 強い成層 状態となっている ${ }^{1)}$. また, 多量の河川水流入が成層状 態をより強化している. この河川水による陸からの栄養 塩供給が，湾内におけるクロロフィル $a$ の変動に大きく 影響している ${ }^{2}$. クロロフィル $a$ の分布に対する研究で は衛星画像を使ったものが多く，水平分布の季節的な変 動やブルームの存在などが見い出されている ${ }^{3)}$. しかし, 実際に湾で観測したデータを使っているものはほとんど ない，そこで，本研究では観測データの解析からクロロ フィル $a$ の鉛直分布の季節的な特徵を明らかにし，その 結果を混合過程を導入した生態系モデル (NPZ モデル) ${ }^{4}$, 5を使用し，クロロフィル $a$ の鈆直分布の変動を混合過 程との関係から明らかにすることを研究の目的とする.

\section{2. 観測結果}

富山湾プロジェクト（富山環境科学センター等）にお いて観測された，CTD（アレック電子製 AAQ1180）デ ータと同時観測しているクロロフィル $a$ のデータを解析
した の. 解析範囲は東経 137 度 00 分から東経 137 度 30 分まで, 北緯 36 度 45 分から 37 度 00 分までの海域に含 まれる 9 地点の水深 $0 \mathrm{~m}$ から約 $50 \mathrm{~m}$ までを対象とする

（図-1）。解析期間は 2004 年から 2008 年までの 5 年間 である．観測は，富山高等専門学校（旧 富山商船高等 専門学校）の「さざなみ」を使用して, st. 6, 3, 1, 2, 5, 4, 7, 9, 8 の順番で反時計回りに一巡 5 時間程度で実施された。 観測時期は毎月末に 1 回観測されているが、CTD デー 夕の数が鉛直方向に毎回異なり, 統一して解析できるよ うに，0〜50mまでを $1 \mathrm{~m}$ ごとに平均して，1 $1 \mathrm{~m}$ に 1 個の 值にしてデータ数を揃え解析した.

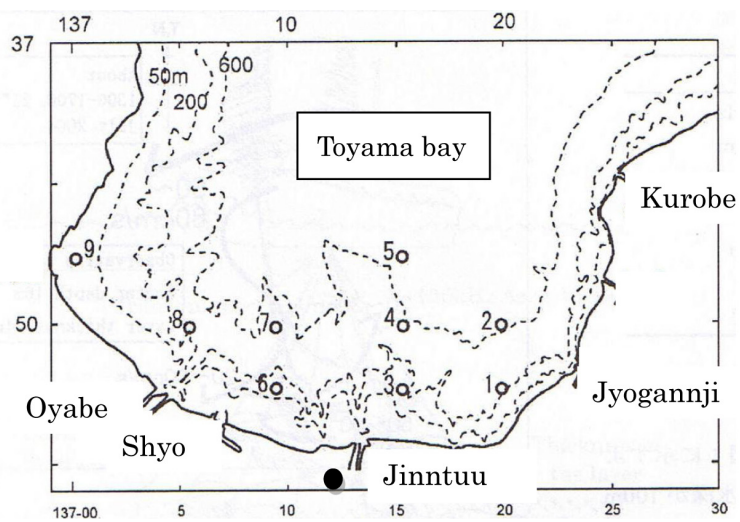

図-1＼cjkstart富山湾沿岸におけるクロロフィル $a$ の観測点と 5 大河川 


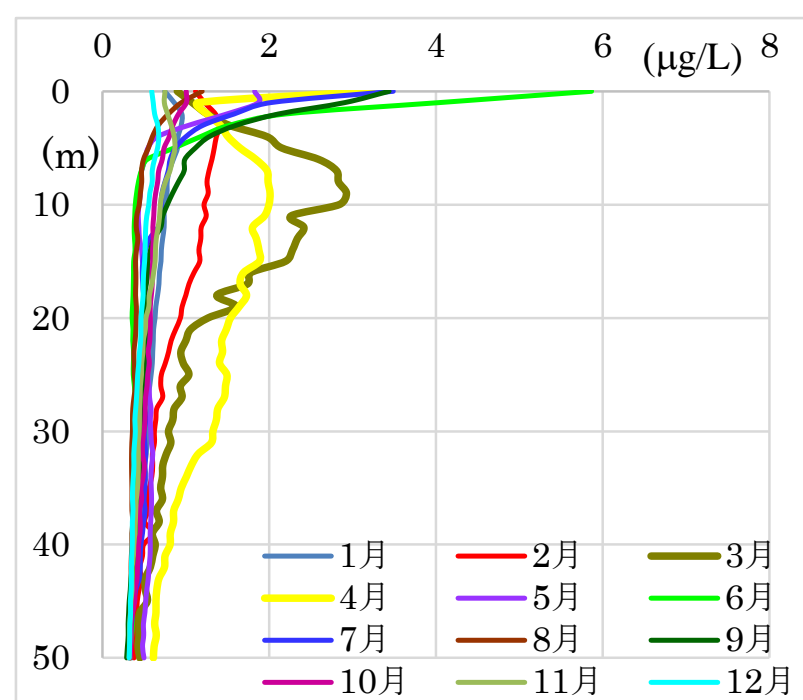

(a)

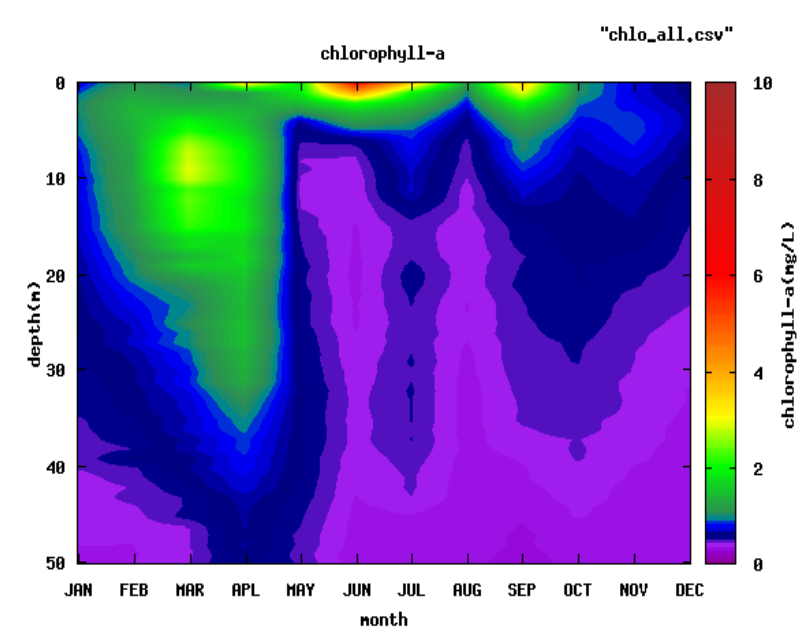

(b)

図-2 2004年から 2008年の富山湾沿岸 9 地点における各月ごとのクロロフィル $a$ の平均值の鉛直分布 (a) と各月の分布を季節的 に連ねたクロロフィル $a$ 分布図 (b)

2004 年から 2008 年の 5 年間のクロロフィル $a$ を月ご とに平均したものを図-2a に示す. クロロフィル $a$ 濃度 は海表面に高い月, 海洋内部（数 $10 \mathrm{~m}$ 深）に高い月, 全体に濃度の低い月の 3 種類に大きく分けることができ る. 海表面に高いのは 6 月， 7 月，9 月であり，海洋内 部に高いのは 2 月，3 月，4月である。 また，全体に低 いのは 10 月， 11 月， 12 月，1月である. 5 月と 8 月は, 海表面に対して全体に濃度の低い月と比べると值は高い が，海表面で高い月と比べると低くなっている．海表面 において最もクロロフィル $a$ 濃度が高いのは 6 月であり 海洋内部において最も高いのは 3 月である. また, 内部 では水深 $10 \mathrm{~m}$ 付近で最大濃度となる. 図-2b は年間での 海洋クロロフィル $a$ の広がりを示しており, この図から クロロフィル $a$ 濃度の区分がよりはっきりとわかる．夏 季は海表面に非常に多く存在しているが，成層が発達し ている月であるため, 他の月よりも水深 $10 \mathrm{~m}$ 前後でク ロロフィル $a$ の濃度が急激に低くなっている．また，春 季は水深約 $40 \mathrm{~m}$ と深いところまで比較的安定してクロ ロフィル $a$ が広がっている.このクロロフィル $a$ の季節 変化は, 海洋の混合過程の季節変化と関連していること が示唆される.

富山県には5つの一級河川があり, 流域で年間降水量 も多いことから多量の河川水が富山湾に流入している. 特に神通川は，流域が多雨地域であるため，県内随一の 流量を誇っている.この5つの河川によって富山湾沿岸 の表層には，低塩分水塊が存在することが分かっている． 流動場との関連で低塩分域は湾東部に広範囲に分布寸る 傾向がある. また，河川流量と低塩分域の面積との間に は正の相関がみられることから，低塩分域の面積の大き さには河川流量の大小が関係していることが示唆される.
また，河川水による栄養塩の供給は河川水の影響が強い 海域で顕著で，それに伴いクロロフィル $a$ の増加も分か っている.このことは，沿岸域の海面付近において河川 水の流入はクロロフィル $a$ の分布に非常に関係がある.

ここで，富山湾への河川流入量が多い 4 月と 7 月の 二つの月に着目する (図-3参照) . 4 月においては, 富 山湾全体の水温がまだ低く, 表層付近のみが大気による 加熱で温まり始めている時期である，また，密度が鉛直 方向にほぼ一定の時期であり, 成層が不安定で混合が起 きや寸い，そこに雪解けの大量の河川水が流入すると， 4 月の低温低密度である河川水は, 鉛直混合が起きてい る中に流入し, 沿岸付近で混合してしまうので沖合まで 広がらないと考えられる.7月において 4 月と比べると, 富山湾全体が高温であり, 海表面付近に密度躍層が発達 しており，成層が安定している時期である. 図-2bにお いてクロロフィル $a$ が海表面付近のみで梁いところにほ とんど存在していないのは, 夏季である湾の水塊が成層 状態となっていることと流入する梅雨による淡水が成層 をより強めていることから, 供給された栄養塩が下層と 混ざることなく, 表層にとどまるためと考えられる.

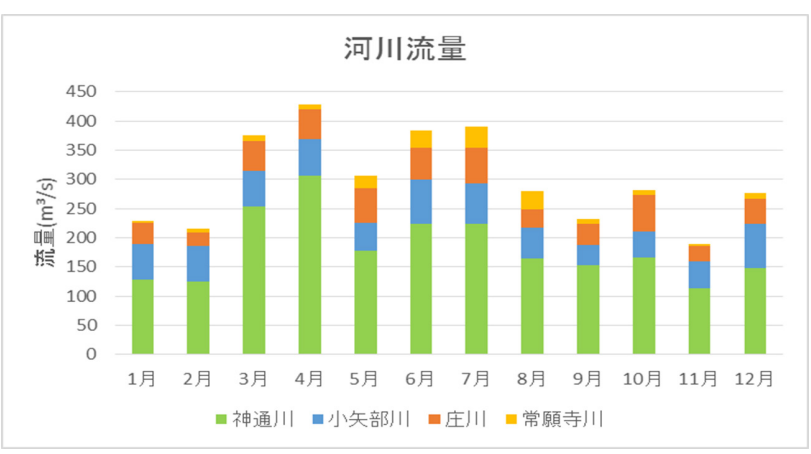

図-3 富山の主な 4河川の月ごとの流量平均值(2004 2008年) 


\section{3. モデリングの概要}

\section{(1) 鉛直混合過程の入ったNPZ モデル}

混合の影響のみをよりはっきり見るために，使用する モデルは生態系モデルの中では最も単純な, 栄養塩 $\mathrm{N}$, 植物プランクトン $\mathrm{P} 、$ 動物プランクトン $\mathrm{Z}$ の 3つの要素 のみを考慮した NPZ モデル4 4)を採用した．NPZ モデル で使用する基本式は以下の 3 つである. 混合過程は (1) と(2)式の右辺最後の項でパラメータ化している.

植物プランクト $\mathrm{P}\left(\mu \mathrm{molN} L^{-1}\right)$

$\frac{d P}{d t}=\frac{V_{m} N P}{k_{s}+N} e^{k_{e x t} z}-R_{m} Z\left(1-e^{-\lambda P}\right)-m P+K_{v} \frac{\partial^{2} P}{\partial z^{2}}$

動物プランクトン Z $\left(\mu m o l N L^{-1}\right)$

$$
\frac{d Z}{d t}=(1-\gamma) R_{m} Z\left(1-e^{-\lambda P}\right)-g Z+K_{v} \frac{\partial^{2} Z}{\partial z^{2}}
$$

栄養塩 $\mathrm{N}\left(\mu \mathrm{molNL} L^{-1}\right)$

$$
N+P+Z=N_{T}
$$

ここで, $\mathrm{z}$ : 深さ $(\mathrm{m}), \mathrm{V}_{\mathrm{m}}$ : P の栄養塩摂取速度 $\left(\mathrm{day}^{-1}\right)$, $\mathrm{k}_{\mathrm{s}}$ : 栄養塩摂取半飽和定数 $\left.(\mu \mathrm{molNL})^{-1}\right), 1 / \mathrm{k}_{\mathrm{ext}}$ : 放射照度 限界水深 $(m), R_{m}$ : 最大植食速度 $\left(\right.$ day $\left.^{-1}\right), \lambda$ : イブレフ定 数 $\left(\mu \mathrm{molNL}^{-1}\right)^{-1}, \gamma$ : 不同化率, $\mathrm{m}$ : P の死亡率 $\left(\mathrm{day}^{-1}\right)$, $\mathrm{g}: \mathrm{Z}$ の死亡率 $\left(\mathrm{day}^{-1}\right), \mathrm{K}_{\mathrm{v}}$ : 鉛直渦拡散係数 $\left(\mathrm{m}^{2} \mathrm{~s}^{-1}\right), \mathrm{N}_{\mathrm{T}}$ : 栄養盐総量 $\left.(\mu \mathrm{molNL})^{-1}\right)^{-1}$ である.

モデルに使用したパラメータの条件は, Edwards et al. (2000)占) に準じて動物プランクトンの大きさを大型（マ クロ）と小型 （ミクロ）の二種類に分け，以下の表-1 のように設定した.

\section{(2) 数值解法とパラメータ}

モデル方程式の差分にはクランクニコルソン法を使用 した. 計算に使用した鉛直拡散係数 $\mathrm{K}_{\mathrm{v}}$ と植食速度の值 $\mathrm{R}_{\mathrm{m}}$ を以下の表-2に示す.

表-1 マクロとミクロ動物プランクトンの代表的パラメータ

\begin{tabular}{lll|ll} 
& \multicolumn{2}{|c}{ 大型(Macro) } & \multicolumn{2}{|c}{ 小型(Micro) } \\
\hline$V_{m}=$ & 2.0 & 2.0 & $\left(\right.$ day $\left.^{-1}\right)$ \\
$k_{s}=$ & 0.1 & 0.1 & $\left(\mu\right.$ molN $\left.^{-1}\right)$ \\
$k_{\text {ext }}=$ & 0.06 & 0.06 & $\left(\mathrm{~m}^{-1}\right)$ \\
$R_{m}=$ & 0.5 & 4.0 & $\left(\right.$ day $\left.^{-1}\right)$ \\
$\lambda$ & $=$ & 0.2 & 0.3 & $\left(\text { (molN }^{-1}\right)^{-1}$ \\
$\gamma$ & $=$ & 0.3 & 0.7 & \\
$\mathrm{~m}=$ & 0.1 & 0.1 & $\left(\right.$ day $\left.^{-1}\right)$ \\
$\mathrm{g}=$ & 0.2 & 0.2 & $\left(\right.$ day $\left.^{-1}\right)$ \\
$N_{T}=$ & 10 & 10 & $\left(\right.$ (molN $\left.^{-1}\right)$
\end{tabular}

\begin{tabular}{|c|c|c|}
\hline & \multicolumn{2}{|c|}{ 植食速度 $\mathrm{Rm}$ (day $\left.^{-1}\right)$} \\
\hline $\begin{array}{l}\text { 鉛直拡散係数 } \mathrm{K}_{\mathrm{v}} \\
\left(\mathrm{m}^{2} \mathrm{~s}^{-1}\right)\end{array}$ & 大型(マクロ） & 小型(ミクロ) \\
\hline 0 & 0.5 & 3.5 \\
\hline $10^{-7}$ & 0.7 & 4.0 \\
\hline $10^{-6}$ & 1.0 & 4.5 \\
\hline $10^{-5}$ & 1.1 & 5.0 \\
\hline $10^{-4}$ & 1.2 & 5.5 \\
\hline $10^{-3}$ & 1.3 & 6.0 \\
\hline \multirow[t]{5}{*}{$10^{-2}$} & 1.5 & \\
\hline & 1.8 & \\
\hline & 2.0 & \\
\hline & \multicolumn{2}{|c|}{2.5} \\
\hline & \multicolumn{2}{|c|}{3.0} \\
\hline
\end{tabular}

表-2 数值実験で実施したパラメータ

本研究では，計算範囲は水深 $\mathrm{H}=65 \mathrm{~m}$ とし，鉛直の解 像度 $\mathrm{dz}=1 \mathrm{~m}$ とした．また，数值計算は陰解法の差分法 を用い時間ステップは $43.2 \mathrm{~s}$ としている. 境界条件は海 面と底 $(\mathrm{z}=0,-\mathrm{H})$ で $\mathrm{dP} / \mathrm{dz}=0, \mathrm{dz} / \mathrm{dz}=0$ のフラックスな しのノイマン条件を課した.

\section{4. 鉛直混合の影響}

富山湾沿岸におけるクロロフィル $a$ の鉛直分布の季節 変化の特徴を鉛直乱流混合過程が第一義的に影響してい ると仮定し，鉛直渦拡散項を入れたNPZモデル ( Edwards et al., 2000) を数值的に調べた結果をここで示す．パラメ 一タとしてマクロ動物プランクトン $\left(\mathrm{R}_{\mathrm{m}}=0.5, \lambda=0.3\right.$, $\gamma=0.7)$ とミクロ動物プランクトン $\left(\mathrm{R}_{\mathrm{m}}=4.0, \lambda=0.2, \gamma=0.3\right)$ に対し, 渦拡散係数 $\mathrm{K}_{\mathrm{v}}\left(\mathrm{m}^{2} \mathrm{~s}^{-1}\right)$ を $0 \leqq \mathrm{~K}_{\mathrm{v}} \leqq 10^{-2}$ の範囲で の比較結果を議論する. マクロの上層 $(0 \sim 25 \mathrm{~m})$ では植 物プランクトンの活動が活発なため, 栄養塩が十分消費 され，P と Z の間で安定な状態に落ち着く. 一方，ミク 口の上層では，栄養塩がマクロの時ほど消費されず富栄 養の状態が保たれ不安定となり，N, P, Z の間で振動する。

\section{(1) マクロプランクトンの場合}

$\mathrm{K}_{\mathrm{v}}=0$ の場合，マクロプランクトン分布の鉛直変動は 表層から $25 \mathrm{~m}$ までは $\mathrm{P}$ と Z が固定点に収束し， $25 \mathrm{~m} \sim 50$ mで振動（リミットサイクル）するが，深くなるにつれ その周期が長くなる（図-4a）。つまり，浅い水深にお いて栄養塩 $\mathrm{N}$ が消費され，Pと Z の間で平衡が保たれて いる. 一方，中間水深 $(30 \mathrm{~m})$ あたりでは光が弱くなり， $\mathrm{P}$ が光合成で栄養塩を消費する量が減る. しかし， N と 被食者 $\mathrm{P}$, 捕食者 $\mathrm{Z}$ のやり取りは不安定であり，その間 で振動が起きている. 


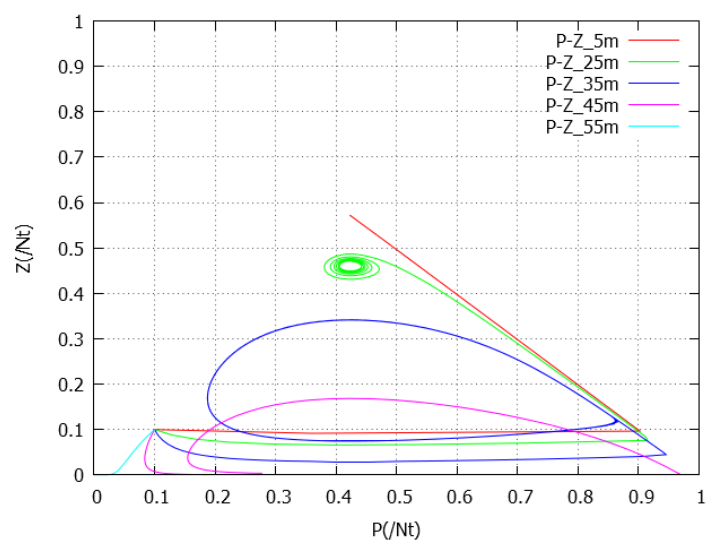

(a) 拡散なし, $\mathrm{K}_{\mathrm{v}}=0\left(\mathrm{~m}^{2} \mathrm{~s}^{-1}\right)$

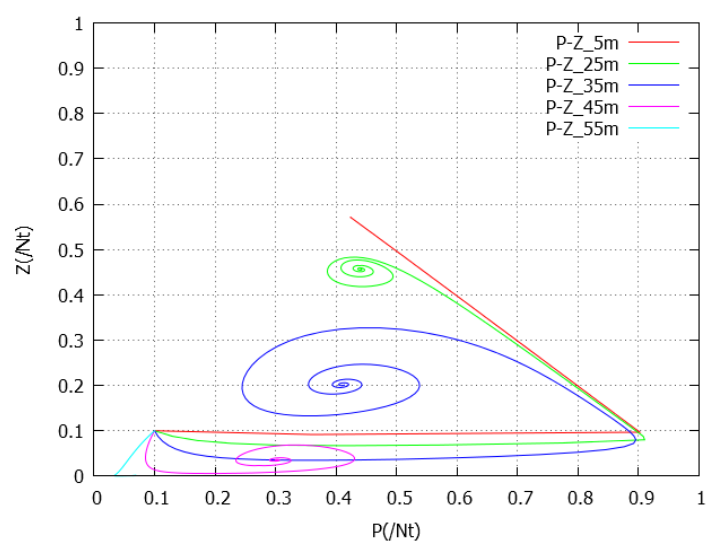

(b) 拡散あり, $\mathrm{K}_{\mathrm{v}}=10^{-5}\left(\mathrm{~m}^{2} \mathrm{~s}^{-1}\right)$

図-4 マクロ動物プランクトン, 植食速度 $\mathrm{Rm}=0.5\left(\mathrm{day}^{-1}\right)$ で 拡散なし(a)とあり(b)の場合の P-Zダイアグラム

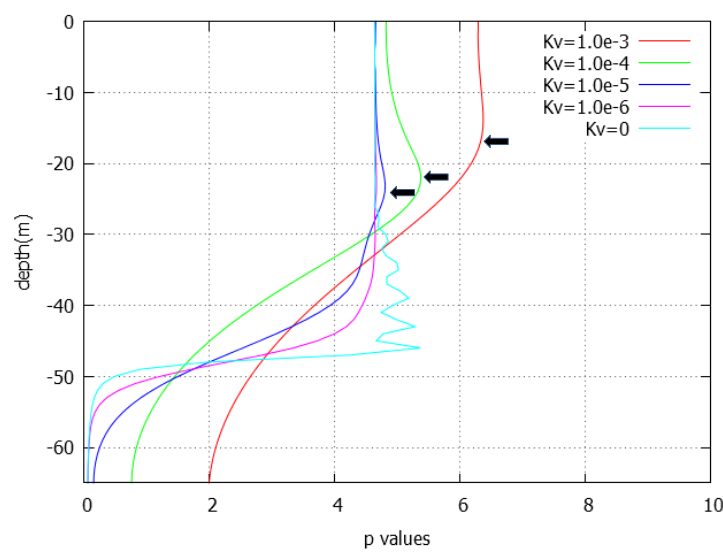

図6 マクロ動物プランクトンで植食速度 $\mathrm{Rm}=0.5\left(\mathrm{day}^{-1}\right)$ に ける拡散係数の違いに対する植物プランクトンの 鉛直分布. 一は極大值の深さの位置を示す.

鉛直拡散係数の影響は，一般的な拡散現象でみられる ように，振動現象を減衰させるように作用する（図-4b と図-5）。また，Pの鉛直分布における最大值は，図-6 に示されるように, $10^{-5}\left(\mathrm{~m}^{2} \mathrm{~s}^{-1}\right) \leqq \mathrm{K}_{\mathrm{v}} \leqq 10^{-3}\left(\mathrm{~m}^{2} \mathrm{~s}^{-1}\right)$ の範囲 で水深 $25 \mathrm{~m}$ から $15 \mathrm{~m}$ の間にあり， $\mathrm{K}_{\mathrm{v}}$ の值が大きくなる につれて上層に移行していく.このPの最大值が現れ
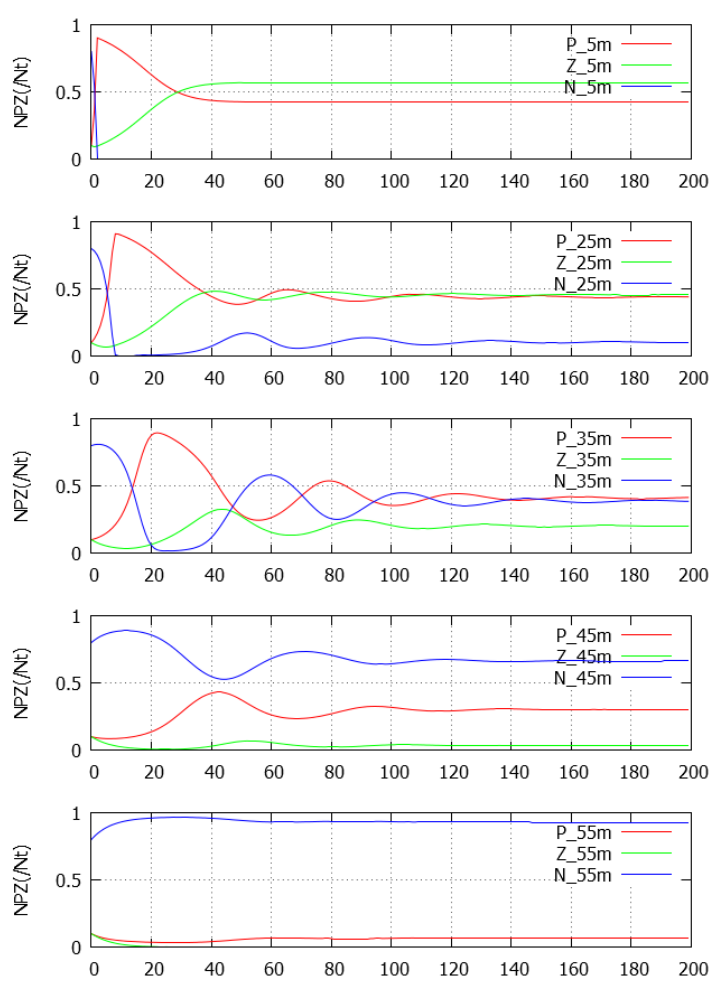

図-5 マクロ動物プランクトンで植食速度 $\mathrm{Rm}=0.5\left(\mathrm{day}^{-1}\right)$, $\mathrm{K}_{\mathrm{v}}=10^{-5}\left(\mathrm{~m}^{2} \mathrm{~s}^{-1}\right)$ の各深さごとの植物プランクトン $(\mathrm{P}$ : 赤), 動物プランクトン( $\mathrm{Z}$ : 緑)、栄養塩( $\mathrm{N}$ : 青)の時間 変化. 縦軸は N,P,Zの量を $\mathrm{N}_{\mathrm{T}}$ で無次元化している.

る水深は丁度 $\mathrm{N}$ の濃度が急激に上昇し，P が減衰する位 置に対応している。 また， $\mathrm{K}_{\mathrm{v}}$ が $10^{-4}\left(\mathrm{~m}^{2} \mathrm{~s}^{-1}\right)$ と $10^{-3}\left(\mathrm{~m}^{2} \mathrm{~s}^{-1}\right)$ になると $35 \mathrm{~m}$ 以深でも $\mathrm{P}$ と Z の存在が顕著であり, こ れは下層への強い拡散の影響が現れていると考えられる.

\section{(2) ミクロプランクトンの場合}

$\mathrm{K}_{\mathrm{v}}=0$ の場合, ミクロプランクトンではマクロプラン クトンと異なり, 表層ほど $\mathrm{N}, \mathrm{P}, \mathrm{Z}$ 間での振動が大きく, 周期が短くなる（図-7a）。拡散が入っても図-7 と図-8 に示されるように，特に上層の方で振幅の大きな変動が みられる. ところで，ミクロの振動の仕方は規則的だが マクロの P-Z アトラクター (図-4) と異なり, その変動 はパルス的である（図-7, 図-8 参照 ）。さらに, ミク ロでは拡散が入ると下層の周期の長い振動は減衰するが, 拡散係数が大きくなるにつれ上層の変動が下層まで一様 に現れる（図省略）。

\section{5. 富山湾の観測のモデル結果からの検討}

第2章の観測データ解析の結果より，富山湾のクロロ フィルaの分布には，2 4月の春季と6 7月の夏季で違い があり，春季には水深 $10 \mathrm{~m}$ 付近の内部で最大濃度とな ることを示した，富山湾は春季，特に3月に混合が最も 活発になり夏季の7, 8月に成層が強くなる ${ }^{1)}$. 混合の活 


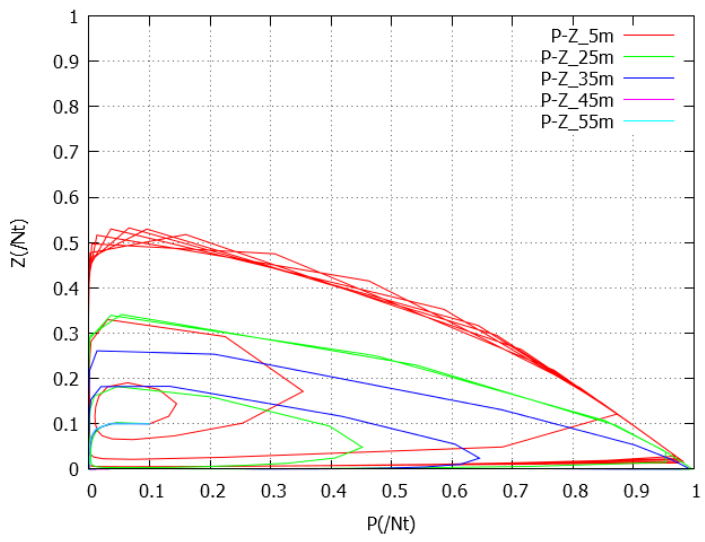

(a) 拡散なし, $\mathrm{K}_{\mathrm{v}}=0\left(\mathrm{~m}^{2} \mathrm{~s}^{-1}\right)$

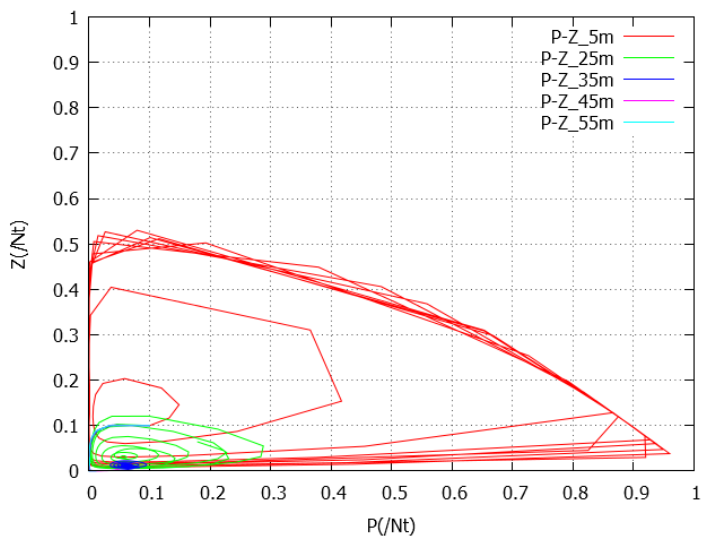

(b) 拡散あり， $\mathrm{K}_{\mathrm{v}}=10^{-5}\left(\mathrm{~m}^{2} \mathrm{~s}^{-1}\right)$

図-7 ミクロ動物プランクトン, 植食速度 $\mathrm{Rm}=4.0\left(\mathrm{day}^{-1}\right)$ で拡 散なし(a)とあり (b) $\mathrm{K}_{\mathrm{v}}=10^{-5}\left(\mathrm{~m}^{2} \mathrm{~s}^{-1}\right)$ の場合の P-Z ダイア グラム

発な春季は深くまで大きなクロロフィルaの鈆直拡散を 示している，そこで，富山湾の3 4月（図-2a）を想定し て，マクロプランクトンの $\mathrm{R}_{\mathrm{m}}=0.7$ で $\mathrm{K}_{\mathrm{v}}$ に対し上層 $10 \mathrm{~m}$ まで大きな值 $10^{-4}\left(\mathrm{~m}^{2} \mathrm{~s}^{-1}\right)$ とし, それ以深を $10^{-5}\left(\mathrm{~m}^{2} \mathrm{~s}^{-1}\right)$ と一般的に設定される值として計算した結果を図-9 に 示す.モデリングの P の鉛直分布は 4月 の観測されたク ロロフィルaの鉛直分布を再現し，10 m 付近に極大值を 持ち, さらに $30 \mathrm{~m}$ 付近に再度極大值を持つ結果を示し ている. したがって，本研究のモデリングは，非常に単 純化したものであるが，観測結果においてクロロフィル $a の$ 鉛直分布に海洋の鉛直混合（乱流混合）過程が本質 的に重要な役割を果たしてることを示している.

一般的に海洋の鉛直拡散係数 $\mathrm{K}_{\mathrm{v}}=10^{-5}\left(\mathrm{~m}^{2} \mathrm{~s}^{-1}\right)$ と推定 されており，これを基準とすると第2章のモデルの結果 から鉛直拡散係数が $\mathrm{K}_{\mathrm{v}}=10^{-4}$ や $10^{-3}\left(\mathrm{~m}^{2} \mathrm{~s}^{-1}\right)$ と大きな係数 をとったとき，マクロでは鉛直分布は海洋内部において 最大となることがわかった（図-6）。逆に $K_{\mathrm{v}}=10^{-5} や 10$ ${ }^{-6}\left(\mathrm{~m}^{2} \mathrm{~s}^{-1}\right)$ と小さいときはほぼ一定となっており, ミク ロでは4パターンの鈶直拡散係数全てで表層が最大とな っていた（図省略）。このことからも，混合が最も発達
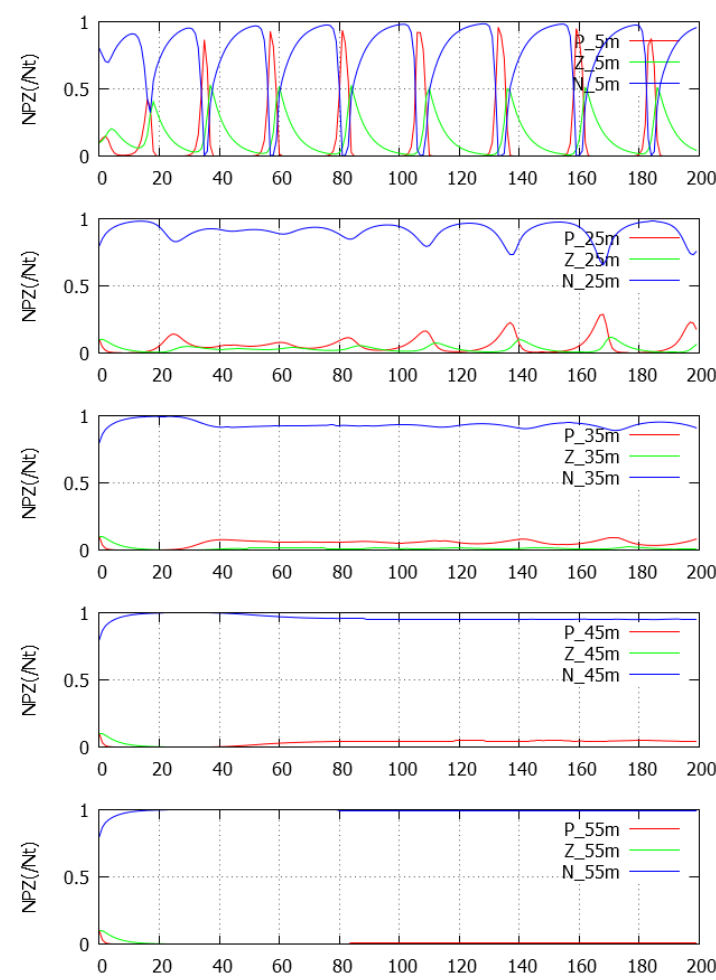

図-8 ミクロ動物プランクトンで植食速度 $\mathrm{Rm}=4.0\left(\mathrm{day}^{-1}\right)$ お よび $\mathrm{K}_{\mathrm{v}}=10^{-5}\left(\mathrm{~m}^{2} \mathrm{~s}^{-1}\right)$ の各深さごとの植物プランクトン $(\mathrm{P}:$ 赤)、動物プランクトン( $\mathrm{Z}:$ 緑)、栄養塩 $(\mathrm{N}$ : 青)の 時間変化. 縦軸はN $, \mathrm{P}, \mathrm{Z}$ の量を $\mathrm{N}_{\mathrm{T}}$ で無次元化している.

する春季に海洋内部で最大となった鉛直分布は，大きな 鉛直拡散で内部が最大となったモデルの結果と対応して おり，鉛直拡散係数が重要な要因であると考えられる.

ところで，マクロで植食速度 $\mathrm{R}_{\mathrm{m}}$ が大きくなると大き な鉛直拡散係数でも表層が最大となった結果から，富山 湾の春季に海洋内部で最大となるためには，動物プラン クトンが植物プランクトンを消費する速さが緩やか，つ まり $\mathrm{R}_{\mathrm{m}}$ の值が小さいことが条件であると考えられる.

富山湾は河川水の流入が多く, 表層では栄養塩が豊富 であることが明らかになっている。そのため春季であっ

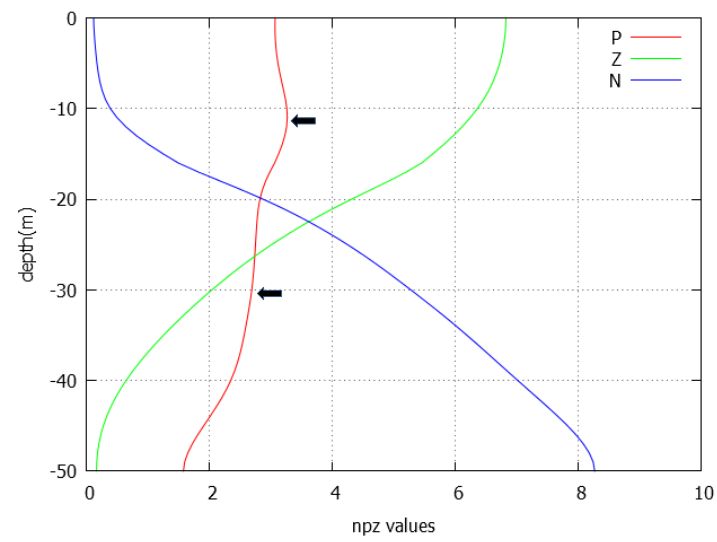

図-9 マクロ動物プランクトンで植食速度 $\mathrm{Rm}=0.7\left(\mathrm{day}^{-1}\right)$ て $\mathrm{K}_{\mathrm{v}}$ に対し上層 $10 \mathrm{~m}$ まで $10^{-4}\left(\mathrm{~m}^{2} \mathrm{~s}^{-1}\right)$, それ以深を $10^{-5}$ $\left(\mathrm{m}^{2} \mathrm{~s}^{-1}\right)$ 対寸る $\mathrm{N}, \mathrm{P}, \mathrm{Z}$ の鉛直分布. 
ても3 4月は雪解け水による河川水の増加にともない植 物プランクトンも表層が最大となるが，モデル結果との 対応から春季の富山湾のクロロフィル $a$ 鉛直分布が海洋 内部において最大となるのは，活発な混合が影響してい るためと判断される。.また，夏季においては豊富な日射 量と栄養塩があり, 植物プランクトンは十分に増えるこ とができ, 春季と比べると動物プランクトンの活動も活 発である. そのことから推察すると，モデル結果では植 食速度 $\mathrm{R}_{\mathrm{m}}$ 值が大きい場合は 4 パターンどの鉛直拡散係 数でも表層が最大となっており (図省略)，動物プラン クトンが活発な場合は鉛直㵝拡散係数ではなく植食速度 にも依存している可能性も考えられる.

\section{6. まとめ}

富山湾のクロロフィル $a$ の分布には 2 4 月の春季と 6 7 月の夏季で違いがあることがわかった（図-2）。春 季は水深 $10 \mathrm{~m}$ 付近において最大となり, 夏季は海表面 において最大となることが観測データの解析より示され た. そこで，春季の 3 月は富山湾では最も混合が活発に なる時期であることから, 混合過程が要因の一つである と予想し，モデルを使って影響を調べるために生態系モ デルに鉛直渦拡散係数を導入し，モデル実験を行った.

鉛直渦拡散係数の大きさの影響を調べたところ，適切 なパラメータ設定に対し，モデル結果として植物プラン クトンの鉛直分布が適切に再現された（図-9）。また, マクロにおける拡散が大きい $\mathrm{K}_{\mathrm{v}}=10^{-4}\left(\mathrm{~m}^{2} \mathrm{~s}^{-1}\right)$ の場合に 海洋内部において, 鉛直分布は表層ではなく内部で最大 となった，そして，ミクロとマクロに関わらず，深部ま で表層と近い変動を示していることから，鉛直渦拡散係 数が大きいほど深部へと影響することがわかった.

拡散が小さい場合，特にミクロの場合に海面で最大と なったが時間変化の鉛直断面困から，植物プランクトン が安定して増加することができるのは，植物プランクト ン量の急激な変化や減衰振動を示したおおよそ水深約
$35 \mathrm{~m}$ までであると判断された.

富山湾沿岸における鉛直渦拡散係数は，混合によって 春季は拡散係数が大きくなり, 夏季は成層が強化され, 混合が抑制されることで拡散係数は小さくなっているの で，モデルの結果と対応する傾向を示している. 以上よ り，富山湾沿岸におけるクロロフィル $a$ の鉛直分布には 混合が大きく影響していると考えられる.

謝辞 : 本研究は富山大学の高低差4000m富山環境プロジ エクトとの一部として実施された．本研究を行う上で富 山湾沿岸の観測データを提供していただいた公益財団法 人環日本海環境協力センターに対し謝意を表す.

\section{参考文献}

1) 渡邊良美, 松浦知徳, 千葉元: 富山湾沿岸における夏季海 洋鉛直構造の変動特性，海の研究，Vol. 22, No.4, pp.97117, 2013.

2) 長田宏, 奈倉昇：富山湾における河川水の流入とクロロフ イル $a$ 濃度の季節変動, 日本海区水産研究所研究報告, 43, pp. 55-68, 1993.

3) 大西美奈, 石坂丞二，笠原一世，長田宏，白山肇，内山勇， 寺内元基：海色衛星によって観測された富山湾における 1998 年と 1999 年のクロロフィル $a$ 濃度分布, 海の研究, Vol. 16, pp. 7-22, 2007.

4) Franks, P: NPZ Models of Plankton Dynamics, Their Construction, Coupling to Physics, and Application, J. Oceanogr, Vol. 58, pp. 379387, 2002

5) Edwards, C. A., Powell, T. A. and and Batchelder, H. P.: The stability of an NPZ model subject to realistic levels of vertical mixing, J. Marine Res, Vol. 58, pp. 37-60, 2000.

6) 千葉元 ・ 山下恵 - 小杉廣彦 - 内山勇：富山湾の海水温 度・塩分の季節特性一第 2 報一一実習船「さざなみ」に よる海洋環境計測一：富山商船高等専門学校研修集録, 第 39 号, 2006.

(2016.3.16 受付)

\title{
A STUDY ON VERTICAL DISTRIBUTION OF CHLOROPHYLL A IN TOYAMA BAY FROM AN ECOSYSTEM NODEL INCLUDING DIFFUSION PROCESS
}

\author{
Mitsuyosi OOHASI, Tomonori MATSUURA, Yuto KURODA and Hajime CHIBA
}

In coastal area of Toyama bay, the fresh water with rich nutrient from rivers joins the Tsushima warm water entering from the open sea with high salinity. Thus, the fine oceanic environment is formed and aquatic resources are rich. Recently, however, it becomes important to understand the distributions and variations of ecosystem because of a change for the worse of its environment. Accordingly, we analyzed the observational data of chlorophyll a in Toyama bay coastal-area and investigated its vertical distribution and its changing using one-dimensional ecosystem model (NPZ model). As a result, it was found that the turbulent mixing affected the vertical distribution of phytoplankton in Toyama bay significantly. 